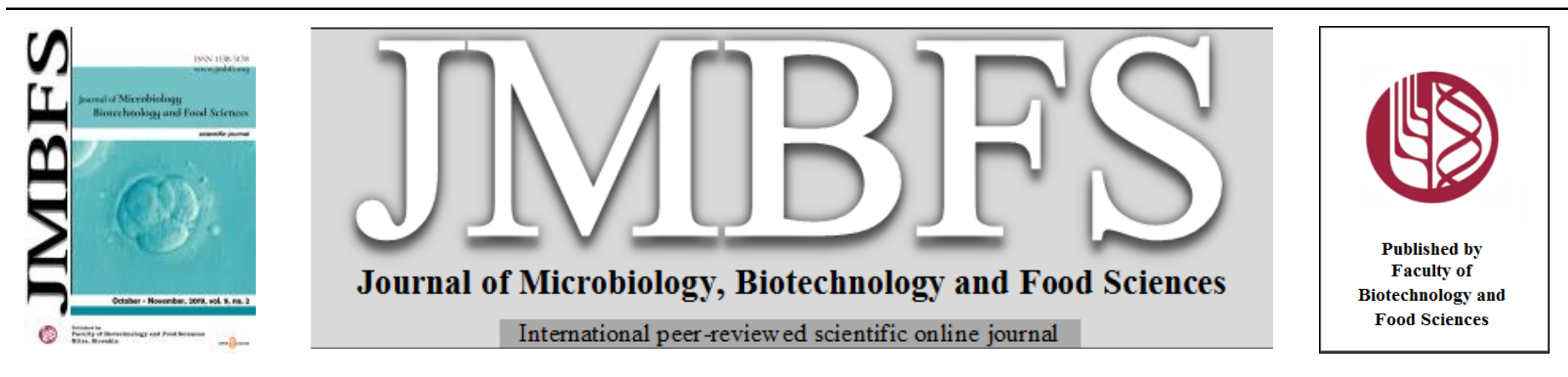

\title{
COMPARATIVE ANALYSIS OF NITROGEN-TO-PROTEIN CONVERSION FACTORS FOR DETERMINING NET PROTEIN CONTENT IN SIX SUPERFOODS
}

\author{
Vennela Gosukonda ${ }^{1}$, Hari Singh ${ }^{2}$, Ramana Gosukonda ${ }^{3}$
}

Address(es): Professor Ramana Gosukonda,

${ }^{1}$ Houston County High School, 920 GA-96, Warner Robins, GA 31088, USA.

${ }^{2}$ Agricultural Research Station, College of Agriculture, Family Sciences and Technology, Fort Valley State University, Fort Valley, GA 31030, USA.

${ }^{3}$ Department of Agricultural Sciences, College of Agriculture, Family Sciences and Technology, Fort Valley State University, Fort Valley, GA 31030, USA. Phone number:001+4788256836

*Corresponding author: gosukonr@fvsu.edu

doi: 10.15414/jmbfs.2020.9.4.856-860

\section{ARTICLE INFO}

Received 8. 4. 2019

Revised 10.9. 2019

Accepted 11. 9. 2019

Published 3. 2. 2020

Regular article OPEN $\partial_{\text {ACCESS }}$

\begin{abstract}
The true protein content of plant foods is best assessed directly by analyzing amino acids quantitatively or indirectly by using a nitrogen-to-protein conversion factor (NPCF) that is computed based on sums of amino acids. The practical way of determining protein in plant foods is by multiplying its total nitrogen (TN) value with a reliable plant-specific NPCF. In this study, three kinds of NPCFs were evaluated for measuring the net-protein content of chia, rye, quinoa, spelt, flax, and hemp. A universal factor of 6.25 was considered NPCF1, while NPCF2s and NPCF3s were based on the sum of amino acids with amide-nitrogen and computed quantities of Asn and Gln using a ratio method, respectively. The TN was minimal in rye $(1.34 \% \mathrm{w} / \mathrm{w})$ and maximal in flax $(5.57 \% \mathrm{w} / \mathrm{w})$. The values of NPCF2 ranged from $5.18-5.90$ and from $5.45-6.22$ for NPCF3. The net protein values obtained by NPCF2 were close to the values of direct quantitative analysis of amino acids as compared to other NPCFs. The use of computed Gln and Asn quantities incorrectly increased the amount of available nitrogen in the amino acids, especially in spelt, flax, and hemp; it was about $4 \%$ higher than the corresponding TN values, suggesting that the use of the computed method is not appropriate for these plants. NPCF1 overestimated the protein content in all the samples. The degree of overestimation is likely due to the inclusion of non-protein nitrogen in the calculation, which ranged from $5 \%-22 \%$ in the samples tested.
\end{abstract}

Keywords: Amino acids, nitrogen-to-protein conversion factor, superfoods, net protein, non-protein nitrogen

\section{INTRODUCTION}

Cereal protein is an important component in both animal feed and human diets, constituting approximately 16 to 45 grams per capita per day (Hackler, 1985). It represents $70 \%$ of the total dietary protein in some areas of the world, thus underscoring the need for an accurate knowledge of the protein concentration of cereals. Lately, seeds of chia (Salvia hispanica), rye (Secale cereale), quinoa (Chenopodium quinoa), spelt (Triticum spelta), flax (Linum usitatissimum), and hemp (Cannabis sativa) have gained the status of superfoods and are often used as dietary supplements as a rich source of energy, fiber, high quality protein, macro-and-micronutrients, and other bioactive compounds (Friedman, 1996; Multari et al., 2016; Pihlanto et al., 2017). Consumption of plant-based protein is healthier than that of animal protein, as intake of high amounts of animal protein has been linked to an increased risk of type II diabetes, cardiovascular disease, colorectal cancer, and early death (Chan et al., 2011; Pedersen et al., 2013), whereas consumption of superfoods has been linked to greater health benefits. However, there are still gaps and inconsistencies in basic knowledge about the true protein content of these superfoods; thus, it is imperative to gain a deeper understanding of protein quantity and quality in superfoods.

Traditionally, the quantification of proteins in foods is based on the total nitrogen (TN) content being multiplied by a 6.25 nitrogen-to-protein conversion factor (NPCF), as it was assumed that protein contains approximately $16 \%$ nitrogen $(100 / 16=6.25)$ (Jones, 1931). This technique assumes that all nitrogen originates from protein, even though nitrogen exists in non-protein nitrogen (NPN) compounds such as nitrates, nitrites, chlorophyll, nucleic acids, and free amino acids (Lourenco et al., 1998). Furthermore, depending on the source, the composition of amino acids varies in foods and the nitrogen content of specific amino acids also varies according to the molecular weight and the number of nitrogen atoms it contains. Consequently, when the single conversion factor is applied for all protein sources, significant errors are introduced in protein estimation. Specifically, the application of a single factor to foods that are rich in NPN compounds (foods made of leaves or fruits) will result in an overestimation of the protein content (Milton and Dintzis, 1981; Sedinger, 1984; Izhaki, 1993; Levey et al., 2000).

The Food and Nutrition Board (1989) recommended that net protein (NP) be determined as the total amount of 20 bound and free amino acids. The advantage to using this approach is that it eliminates the problems associated with the use of the single NPCF 6.25 , as it does not require the NPN content of the food or its relative proportions of specific amino acids (Magomya et al., 2014). Foodspecific NPCFs have been determined for plants (Tkachuk, 1969), edible insects (Janssen et al., 2017), animal feeds (Boisen et al., 2000), and processed dietary foods (Salo-Vaananen and Kovistoinen, 1996). The results of these studies have demonstrated that the food-specific NPCFs were much lower (ranging from 3.24 to 5.51) than the traditionally used factor of 6.25 .

The true nature of NPCF is the ratio of actual seed protein to total nitrogen recovered from 20 protein forming amino acids (Mosse, 1990). Because the amino acids Asparagine (Asn) and Glutamine (Gln) are often hydrolyzed during the chemical process, it is recommended that the amide-nitrogen of Gln and Asn be determined separately and be included in the calculation of the NPCF. However, Ibegbulem et al. (2013) used the ratios of 5.3/4.3 for Asp (Aspartic acid) to Asn, and 6.3/4.2 for Glu (Glutamic acid) to Gln, respectively, for estimating the likely amounts of Gln and Asn in a given amino acid profile. These ratios were based on the observation that the amino acids Asp, Asn, Glu, and Gln have average percentage occurrences of 5.3, 4.3, 6.3, and 4.2, respectively, in 1150 proteins of known amino acid sequences (Nelson and Cox, 2008).

Since the value of the NPCF may vary with the concentration of nitrogen in grains, this study investigated 1) the amount of nitrogen recovered from anhydrous amino acids (NAAA) that included either amide-nitrogen or nitrogen from the computed quantities of Asn and Gln using a ratio method, 2) the universal factor of 6.25 (NPCF1) along with the plant-specific NPCFs based on NAAA with amide-nitrogen (NPCF2) or nitrogen from the computed Asn and 
Gln (NPCF3), for reliably estimating the NP content in six superfoods, and 3) net protein amounts obtained from TN x NPCF1 (NP1), TN x NPCF2 (NP2), and TN x NPCF3 (NP3).

\section{MATERIALS AND METHODS}

\section{Preparation of plant samples}

Seeds of six superfoods, chia (Salvia hispanica), rye (Secale cereale), quinoa (Chenopodium quinoa), spelt (Triticum spelta), flax (Linum usitatissimum), and hemp (Cannabis sativa) were commercially obtained. These seeds were ground using an electric grinder (Cyclotec 1093 Sample Mill) and the samples were then stored in tightly sealed containers prior to analysis.

\section{Determination of TN and net protein (NP1) using NPCF1}

Total nitrogen $(\mathrm{TN})$ content $(\% \mathrm{w} / \mathrm{w})$ was measured via the combustion and Kjeldahl methods. Combustion was carried out by following AOAC Official Method 990.03 (2006) using a LECO TrueSpec C/N Analyzer, whereas the Kjeldahl method was performed according to AOAC 984.13 (A-D) (2006) Results from the Kjeldahl method were used for the analysis as there was no difference in the amount of nitrogen produced by these two methods. The measured nitrogen values were then converted into \% dry weight basis (w/w). To estimate NP1 from each sample, TN content was multiplied by NPCF1 (6.25).

\section{Quantification of amino acids and crude protein (CP) in samples}

Amino acid profiles for each sample were obtained according to AOAC Official Method 982.30 E (a,b,c), chp. 45.3.05, (2006) using ion-exchange chromatography (Hitachi Amino Acid Analyzer, Model L-8900). However, this method could only quantify 18 out of the total 20 protein forming amino acids, as Asn and Gln were hydrolyzed during the process of chemical reaction. The crude protein values were calculated as a sum of 18 protein-forming amino acids in each sample and were referred to as CP1 in this study. Furthermore, the likely amounts of Asn and Gln were estimated using the ratios of 5.3/4.3 for Asp to Asn, respectively, and 6.3/4.2 for Glu to Gln, respectively (Ibegbulem et al., 2013). The crude protein values calculated with the computed amounts of Asn and Gln, along with all other protein forming amino acids, were referred to as $\mathrm{CP} 2$.

\section{Determination of plant specific NPCFs for net protein (NP2 and NP3)}

The total nitrogen from all amino acid residues (NAAA) was calculated by summing the quantities of nitrogen contributed by each amino acid, including that of amide-nitrogen $(\% \mathrm{w} / \mathrm{w})$. A residue is an anhydrous amino acid (AAA) that has the molecular weight of its own minus the molecular weight of $\mathrm{H}_{2} \mathrm{O}$ (i.e. $18 \mathrm{~g}$ in $1 \mathrm{M}$ of each amino acid). Amide-nitrogen was determined as percent ammonia (w/w) released via acid hydrolysis of ground samples for two hour with $3 \mathrm{~N}$ hydrochloric acid (Mosse, 1990). The released ammonia values (\% $\mathrm{w} / \mathrm{w}$ ) were multiplied by $14 / 17$ (atomic mass of nitrogen/atomic weight of nitrogen) in order to obtain the amide-nitrogen quantities. In addition, nitrogen from the computed amounts of Asn and Gln, instead of that from amide-nitrogen, was included in the calculation of NAAA and the effect on NPCFs was evaluated

The upper $\left(\mathrm{k}_{\mathrm{A}}\right)$ and lower $\left(\mathrm{k}_{\mathrm{P}}\right)$ limits of the NPCF were calculated according to Mosse (1990). The upper limit $\left(\mathrm{K}_{\mathrm{A}}=\sum \mathrm{E}_{\mathrm{i}} / \sum \mathrm{D}_{\mathrm{i}}\right)$ is defined as the ratio of actua seed proteins (that is total amino acid residue weight) to total nitrogen recovered from the amino acids and amide nitrogen (or nitrogen from predicted Asn or Gln values), where: $E_{i}$ is the grams of the $i^{\text {th }}$ amino acid residue per 100 grams of sample, dry weight basis, and $D_{i}$ is the grams nitrogen of the $i^{\text {th }}$ amino acid per 100 grams of sample, dry weight basis. The lower limit $\left(K_{P}=\sum E_{i} / T N\right)$ is defined as the ratio of actual seed proteins to TN content in 100 grams of dry seed matter (TN was determined by Kjeldahl method), where: $\mathrm{E}_{\mathrm{i}}$ is the grams of the $\mathrm{i}^{\text {th }}$ amino acid per 100 grams of sample, dry weight basis, and TN is the grams of nitrogen per 100 grams of dry weight.

An appropriate NPCF for each sample was produced by taking the average of the upper and lower limits $\left(\mathrm{NPCF}=\right.$ average $\left.\left(\mathrm{k}_{\mathrm{A}}, \mathrm{k}_{\mathrm{P}}\right)\right)$. However, published reports suggest that the appropriate value for NPCF could vary as a function of nitrogen with possible deviations that plausibly do not exceed $\pm\left(\mathrm{k}_{\mathrm{A}}-\mathrm{k}_{\mathrm{P}}\right) / 4$. Therefore, the maximum plausible error $\left(\mathrm{k}_{1}\right)$ was calculated as $\mathrm{k}_{1}=\left(\mathrm{k}_{\mathrm{A}}, \mathrm{k}_{\mathrm{P}}\right) / 2+\left(\mathrm{k}_{\mathrm{A}}, \mathrm{k}_{\mathrm{P}}\right) / 4$, and the minimum plausible error $\left(\mathrm{k}_{2}\right)$ was calculated as $\mathrm{k}_{2}=\left(\mathrm{k}_{\mathrm{A}}, \mathrm{k}_{\mathrm{P}}\right) / 2-\left(\mathrm{k}_{\mathrm{A}}, \mathrm{k}_{\mathrm{P}}\right) / 4$. Two sets of plant specific factors were calculated: 1) NPCF2, which was based on NAAA with amide-nitrogen being included, and 2) NPCF3, which was based on NAAA that included nitrogen from the computed values of Asn and Gln amino acids. Consequently, two sets of net protein values, NP2 and NP3, were obtained for each sample by multiplying its TN with NPCF2 and NPCF3, respectively.

\section{RESULTS AND DISCUSSION}

Table 1 shows the composition of various amino acids (grams of amino acid per 100 grams of dry sample) and crude protein based on the sum of the amino acids in each of the six superfoods. The results indicate that the amounts of CP2 were, on average, $17.39 \% \pm 1.51$ (mean $\pm \mathrm{SD}$ ) higher than those of $\mathrm{CP} 1$ due to the inclusion of Asn and Gln in CP2 (Table 1). In general, CP1 was the highest in flax (38.78), followed by hemp (35.80) and chia (21.91). The lowest CP1 values were obtained in rye (9.13), followed by quinoa (13.48). Amino acid analysis also indicated the presence of non-proteinogenic amino acids, such as taurine lanthionine, and ornithine at lower levels (data not shown).

Amino acid profiles of flax and hemp were similar with the exception that flax had a higher concentration of glycine $(2.08 \% \mathrm{w} / \mathrm{w})$ as compared to hemp $(1.31$ $\% \mathrm{w} / \mathrm{w})$. The bulk of CP2 in flax $(56.00 \%)$ and hemp $(56.48 \%)$ consisted of the amino acids Asp, Asn, Glu, Gln, Leu, and Arg, whereas Glu and Gln dominated the amino acid profiles of chia, rye, quinoa, and spelt. The amino acid compositions obtained in this study for chia, rye, and quinoa were consistent with the values from published literature (FAO, 1981; Fujihara et al., 2008; Nitrayova et al., 2014).

In general, the amount of amide-nitrogen (\%) that was retrieved from each sample was very small. While flax and hemp yielded the maximum amounts of \% amide-nitrogen $(0.0238$ and 0.03304 , respectively), there was little variance among other samples. In contrast, the nitrogen content $(\%)$ calculated from the computed Asn and Gln values of flax and hemp, was 1.37 and 1.17, respectively. The variations in the amino acid composition and the choice of methods for obtaining nitrogen from Asn and Gln affected the available nitrogen and the subsequent calculations of the NPCFs in the six superfoods.

The results in Table 2 indicate that the average TN content per 100 grams of dry sample was $3.34 \pm 1.84$ grams among the six superfoods and ranged from 1.34 grams in rye to 5.57 grams in flax. Inclusion of nitrogen from computed amounts of Asn and Gln instead of amide-nitrogen in the amino acid profiles increased 1) the total nitrogen recovery from amino acids by $29.71 \pm 4.40 \%$, and 2) the NPCF3 values, derived as the average of $\mathrm{k}_{\mathrm{A}}$ and $\mathrm{k}_{\mathrm{P}}$, by $5.54 \pm 0.46 \%$, but decreased the variance between the values of $\mathrm{k}_{\mathrm{A}}$ and $\mathrm{k}_{\mathrm{P}}$ and $\mathrm{k}_{1}$ and $\mathrm{k}_{2}$. The reason could be that these values vary as a function of nitrogen, and the observed difference between NAAA and that of its TN obtained from a dry sample (Fig. 1 and Fig. 2) was negligible. Because the amount of nitrogen recovered from amide was much smaller than the amount recovered from computed Asn and Gln, the NPCF2s obtained for the six superfoods were also lower as compared to the NPCF3s. The plant-specific NPCFs obtained in this study were lower than that of traditionally used NPCF1 (6.25). The results of this study corroborate the findings of Mosse (1990) that the NCPF for a given cereal grain or oil seed may not necessarily be an inverse of nitrogen percentages of total proteins. For instance, low nitrogen content of rye $(\mathrm{NAAA}=0.98 \%)$ resulted in the NPCF2 value of 5.65 , while high nitrogen content of hemp (NAAA $=4.51 \%$ ) produced an NPCF2 of 5.21. In contrast, the low nitrogen content of quinoa (NAAA = $1.65 \%)$ resulted in a low NPCF2 (5.18) for this plant. The value of the NPCFs varied with the concentration of nitrogen in the grains; in general, the greater the difference between $\mathrm{k}_{\mathrm{A}}$ and $\mathrm{k}_{\mathrm{P}}$ values, the higher the NPCF values. Similarly, in the study by Mosse (1990), the true NPCF for rice grains ranged from 5.1 (low nitrogen containing rice) to 6.0 (high nitrogen containing rice), whereas the NPCFs for barley, soybean, and sorghum were not affected significantly by the nitrogen content of grains. The values of NPCF2 for quinoa were very close to the values reported by Fujihora $\boldsymbol{e t}$. $\boldsymbol{a l}$. $\mathbf{( 2 0 0 8 )}$ for the same plant; however, the values of NPCF were higher for rye when compared to the values of NPCF2 of the current study. Also, the TN value reported for rye was higher $(1.63 \%)$ than that of the TN value $(1.34 \%)$ obtained in this study. 
Table 1 Amino acid composition (grams/100 grams of protein) and amide-nitrogen (\%) of six superfoods

\begin{tabular}{|c|c|c|c|c|c|c|}
\hline Amino acid & Chia & Rye & Quinoa & Spelt & Flax & Hemp \\
\hline Alanine (Ala) & 0.93 & 0.36 & 0.56 & 0.43 & 1.54 & 1.27 \\
\hline Arginine (Arg) & 1.96 & 0.37 & 1.12 & 0.55 & 3.20 & 4.19 \\
\hline Aspartic acid (Asp) & 1.64 & 0.62 & 1.10 & 0.63 & 3.23 & 3.16 \\
\hline Cysteine (Cys) & 0.44 & 0.21 & 0.22 & 0.31 & 0.61 & 0.53 \\
\hline Glutamic acid (Glu) & 3.04 & 1.75 & 1.86 & 3.56 & 6.41 & 4.94 \\
\hline Glycine (Gly) & 0.91 & 0.36 & 0.67 & 0.49 & 2.08 & 1.31 \\
\hline Histidine (His) & 0.53 & 0.18 & 0.38 & 0.29 & 0.72 & 0.90 \\
\hline Isoleucine (Ile) & 0.75 & 0.29 & 0.53 & 0.46 & 1.50 & 1.32 \\
\hline Leucine (Leu) & 1.28 & 0.50 & 0.85 & 0.85 & 1.99 & 2.08 \\
\hline Lysine (Lys) & 1.10 & 0.34 & 0.76 & 0.37 & 1.36 & 1.21 \\
\hline Methionine (Met) & 0.59 & 0.14 & 0.26 & 0.22 & 0.61 & 0.75 \\
\hline Phenylalanine (Phe) & 1.01 & 0.35 & 0.54 & 0.58 & 1.64 & 1.46 \\
\hline Proline (Pro) & 0.71 & 0.65 & 0.46 & 1.17 & 1.24 & 1.16 \\
\hline Serine (Ser) & 0.93 & 0.32 & 0.51 & 0.50 & 1.38 & 1.45 \\
\hline Threonine (Thr) & 0.72 & 0.28 & 0.47 & 0.36 & 1.28 & 1.11 \\
\hline Tryptophan (Try) & 0.19 & 0.07 & 0.12 & 0.12 & 0.46 & 0.27 \\
\hline Tyrosine (Tyr) & 0.63 & 0.14 & 0.34 & 0.31 & 0.89 & 1.23 \\
\hline Valine (Val) & 0.95 & 0.39 & 0.60 & 0.55 & 1.75 & 1.61 \\
\hline $\begin{array}{l}\text { Crude Protein } 1 \text { (CP1) } \\
\text { (total amino acids) }\end{array}$ & 18.31 & 7.32 & 11.35 & 11.75 & 31.89 & 29.95 \\
\hline Asparagine (Asn)* & 1.33 & 0.50 & 0.89 & 0.51 & 2.62 & 2.56 \\
\hline Glutamine (Gln)* & 2.27 & 1.19 & 1.24 & 2.37 & 4.27 & 3.29 \\
\hline $\begin{array}{l}\text { Crude Protein } 2 \text { (CP2) } \\
(\mathrm{CP} 1+\text { Asn+Gln) }\end{array}$ & 21.91 & 9.01 & 13.48 & 14.63 & 38.78 & 35.80 \\
\hline Amide-nitrogen (\% w/w) & 0.00224 & 0.00112 & 0.00306 & 0.00374 & 0.0238 & 0.03304 \\
\hline
\end{tabular}

Table 2 Nitrogen-to-protein conversion factors (NPCFs) of each superfood based on amino acid composition and total nitrogen content.

\begin{tabular}{|c|c|c|c|c|c|c|c|c|}
\hline Plant & $\begin{array}{c}\text { Total } \\
\text { nitrogen }(\% \\
\text { w/w) in } \\
\text { sample }(\mathrm{TN}) \\
\end{array}$ & $\begin{array}{c}\text { Total AAA } \\
(\%) \text { in sample } \\
\left(E_{i}\right)\end{array}$ & $\begin{array}{c}\text { Total } \\
\text { nitrogen } \\
(\%) \text { in } \\
\text { AAA }\left(D_{i}\right) \\
\end{array}$ & $\frac{\mathbf{k}_{\mathbf{A}}}{\left(\sum E_{i} / \sum D_{i}\right)}$ & $\begin{array}{c}\mathbf{k}_{\mathbf{P}} \\
\left(\sum \boldsymbol{E}_{\boldsymbol{i}} / \mathbf{T N}\right)\end{array}$ & $\mathbf{k}_{1}$ & $\mathbf{k}_{2}$ & $\begin{array}{c}\text { NPCF } \\
\text { (Average of } k_{A} \\
\left.\& k_{P}\right)\end{array}$ \\
\hline \multirow{2}{*}{ Chia } & \multirow{2}{*}{3.39} & 15.76 & 2.66 & 5.94 & 4.65 & 5.62 & 4.97 & $5.30^{*}$ \\
\hline & & 18.92 & 3.37 & 5.61 & 5.58 & 5.60 & 5.59 & $5.59 * *$ \\
\hline \multirow{2}{*}{ Rye } & \multirow{2}{*}{1.34} & 6.39 & 0.98 & 6.54 & 4.77 & 6.09 & 5.21 & $5.65^{*}$ \\
\hline & & 7.87 & 1.31 & 6.0 & 5.87 & 5.97 & 5.90 & $5.93^{* *} *$ \\
\hline \multirow{2}{*}{ Quinoa } & \multirow{2}{*}{2.19} & 9.77 & 1.65 & 5.91 & 4.46 & 5.54 & 4.82 & $5.18^{*}$ \\
\hline & & 11.62 & 2.07 & 5.59 & 5.31 & 5.52 & 5.38 & $5.45^{* *}$ \\
\hline \multirow{2}{*}{ Spelt } & \multirow{2}{*}{2.01} & 10.12 & 1.50 & 6.76 & 5.04 & 6.33 & 5.47 & $5.90 *$ \\
\hline & & 12.64 & 2.06 & 6.14 & 6.29 & 6.18 & 6.25 & $6.22 * *$ \\
\hline \multirow{2}{*}{ Flax } & \multirow{2}{*}{5.57} & 27.43 & 4.55 & 6.03 & 4.93 & 5.75 & 5.20 & $5.48^{*}$ \\
\hline & & 33.44 & 5.92 & 5.65 & 6.00 & 5.73 & 5.91 & $5.82 * *$ \\
\hline \multirow{2}{*}{ Hemp } & \multirow{2}{*}{5.53} & 25.88 & 4.51 & 5.74 & 4.68 & 5.47 & 4.94 & $5.21^{*}$ \\
\hline & & 30.97 & 5.68 & 5.45 & 5.60 & 5.49 & 5.56 & $5.52 * *$ \\
\hline
\end{tabular}

AAA = Anhydrous Amino Acid, $\mathrm{k}_{\mathrm{A}}=$ NPCF's maximum upper limit, $\mathrm{kP}_{\mathrm{P}}=$ NPCF's minimum lower limit, $\mathrm{k}_{1}=$ NPCF's plausible upper limit, $\mathrm{k}_{2}=\mathrm{NPCF}$ 's plausible lower limit, NPCF was estimated as the average of $\mathrm{k}_{\mathrm{A}}$ and $\mathrm{k}_{\mathrm{P}}$. ${ }^{\mathrm{N} P C F} 2$ and $* * \mathrm{NPCF} 3$.

The results in Fig. 1 show that the average non-protein nitrogen (NPN) levels among the six superfoods were $22.53 \pm 3.66 \%$ after NAAA (amide-nitrogen being included) amounts were subtracted from $\mathrm{TN}$ of the corresponding samples. The average NPN value was more than the 7\% reported in cereals by Fujihara $\boldsymbol{e}$ al. (2008). Furthermore, the $18.31 \%$ NPN obtained in flax (amide-nitrogen included) in the current study was lower than the $21.7 \%$ NPN reported by Singh et al. (2011) for the same cereal. However, when NAAA (including nitrogen from computed values of Asn and Gln) was subtracted from TN, low to negative levels of NPN were obtained (Fig. 2). In the cases of spelt, flax, and hemp, negative NPN values were observed because their NAAA levels were, on average, $4 \%$ higher than their TN values (Fig. 2). This suggested that the use of ratios for estimating amounts of Asn and Gln is not appropriate in measuring net protein in six superfoods, as the ratios accounted for higher amounts of Asn and Gln than are normally available in these plants.

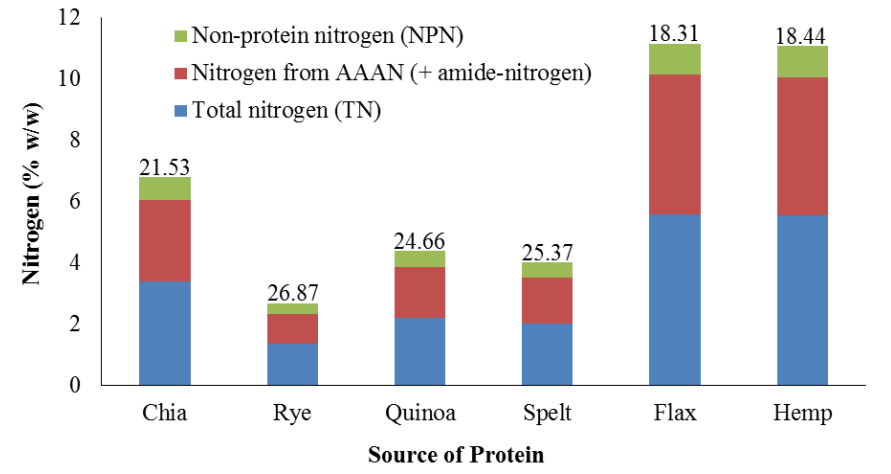

Figure 1 Total nitrogen (TN), nitrogen recovered from anhydrous amino acids (NAAA with amide-nitrogen), and non-protein nitrogen (NPN) in six superfoods. Non protein nitrogen represents the difference between the TN obtained from 100 
grams of dry sample and the NAAA. The numerical values above the bars represent the percent NPN in the TN per superfood.

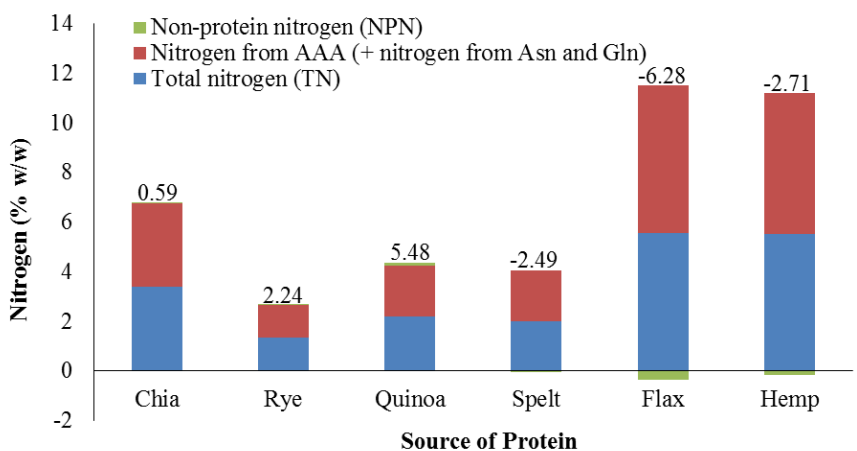

Figure 2 Total nitrogen (TN), nitrogen recovered from anhydrous amino acids (NAAA with nitrogen from the computed quantities of Asn and Gln), and nonprotein nitrogen (NPN) in six superfoods. Non protein nitrogen represents the difference between the $\mathrm{TN}$ obtained from 100 grams of dry sample and the NAAA. The numerical values above the bars represent the percent NPN in the TN per superfood.

Table 3 indicates that the protein content varies with the source of plant material, as it was the highest in flax and the lowest in rye. The contents of NP1 were higher than those of NP2 in all superfoods, which ranged from $8.38 \%$ in rye to $34.57 \%$ in flax (Table 3 ). The reason for such high values could be the use of the universal factor of 6.25 in the estimation of NP1 values. On average, NP3 (TN x NPCF3) values were $5.56 \pm 0.45 \%$ greater than NP2 (TN x NPCF2) values of a given plant (Fig. 3). This observed difference in net protein levels of NP3 and NP2 corresponds to the average difference of $5.54 \pm 0.46 \%$ between NPCF3 and NPCF2 (Table 2). Similarly, CP1 levels were lower $(21.19 \pm 2.27$ $\%$ ) than the CP2 levels, which included additional Asn and Gln amino acids. An array of protein values reported by published literature for each of the six superfoods (Dvoracek et al., 2002; Singh et al., 2011; Nitrayova et al., 2014; Russo and Reggiani, 2015; Shen et al., 2018) was higher compared to CP1, CP2, NP1, NP2, or NP3 amounts obtained in this study (Table 3).

Table 3 Comparison of protein values from literature, crude protein, and net protein in six superfoods.

\begin{tabular}{|c|c|c|c|c|c|c|}
\hline \multirow{2}{*}{$\begin{array}{l}\text { Plant } \\
\text { sample }\end{array}$} & \multirow{2}{*}{$\begin{array}{c}\text { Protein based } \\
\text { on literature } \\
(\%)\end{array}$} & \multicolumn{2}{|c|}{ Crude Protein (sum of AA) } & \multicolumn{3}{|c|}{ Net Protein } \\
\hline & & $\mathrm{CP} 1$ & $\mathrm{CP} 2$ & $\begin{array}{c}\text { NP1 } \\
(\mathrm{TN} \times \mathrm{xPCF} 1)\end{array}$ & $\begin{array}{c}\text { NP2 } \\
(\mathrm{TN} \times \mathrm{NPCF} 2)\end{array}$ & $\begin{array}{c}\mathrm{NP3} \\
(\mathrm{TN} \times \mathrm{NPCF} 3)\end{array}$ \\
\hline Chia & $19-26$ & 18.31 & 21.91 & 21.19 & 17.97 & 18.95 \\
\hline Rye & $10-14$ & 7.44 & 9.13 & 8.38 & 7.57 & 7.95 \\
\hline Quinoa & $13-16$ & 11.35 & 13.48 & 13.69 & 11.34 & 11.94 \\
\hline Spelt & $13-15$ & 11.75 & 14.63 & 12.57 & 11.86 & 12.50 \\
\hline Flax & $20-25$ & 31.89 & 38.78 & 34.81 & 30.52 & 32.42 \\
\hline Hemp & $23-35$ & 29.95 & 35.80 & 34.56 & 28.81 & 30.53 \\
\hline
\end{tabular}

$\mathrm{AA}=\mathrm{Amino}$ acids, CP1 is without Asn and Gln, CP2 is with Asn and Gln, NPCF1 value is 6.25 .

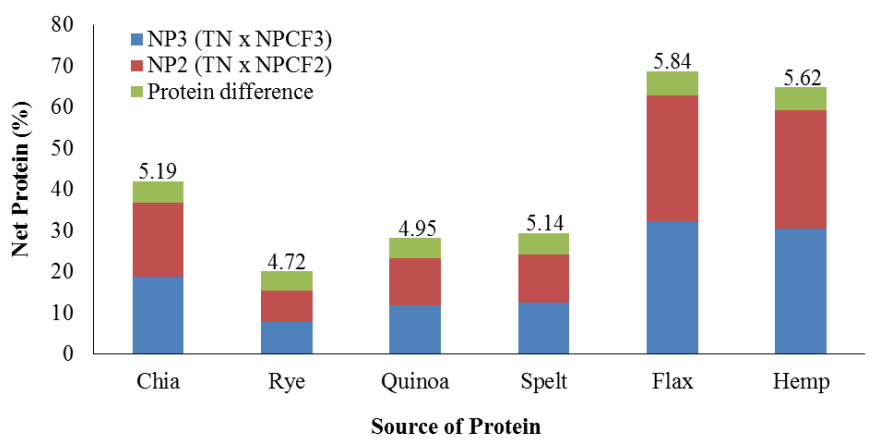

Figure 3 Net protein content of NP2 and NP3 among six superfoods. The numerical values above the bars represent the percent protein difference between NP2 and NP3 per superfood.

In general, the summation of amino acid residues best represented the true protein content in a sample. Though the values of NP2 in this study were comparable to those of CP1 values (Table 3), they were slightly higher than the sum of AAA values (Table 2) in each sample. The differences could be due to the presence of NPN in significant amounts in these cereal grains (except flax) which may have slightly impacted the calculation of protein. Otherwise, the net protein (NP2) obtained by NPCF2 in each sample would have been in good agreement with the sum of amino acid residues. Furthermore, these results suggest that the use of amide nitrogen is more appropriate than the use of computed values of Asn and Gln in the determination of NPCFs.

Finding a perfectly accurate NPCF for reliably estimating the true protein content of a plant food is not possible as it is affected by the plant's genotype, geographical location, and amino acid composition, as well the presence of NPN (\%) in its total nitrogen (Misra, 2001). Furthermore, it is a known fact that analytical procedures cannot accomplish $100 \%$ recovery of amino acids from a given sample (Fujihora et $\boldsymbol{a l}$., 2008). Therefore, each NPCF varies from the average ratio of its $\mathrm{k}_{\mathrm{A}}$ and $\mathrm{k}_{\mathrm{P}}$ values. Hence, the adjusted NPCFs may provide a better estimate of the protein content of plant foods that contains significant levels of non-protein nitrogen (Mosse, 1990).

\section{CONCLUSION}

In conclusion, the true protein values of these six superfoods should be based on the direct quantitative analysis of amino acids or indirect calculation of the NPCFs with a prerequisite that NPCFs be computed using sums of amino acids, including amide nitrogen. The use of the ratio method for computing the amounts of Asn and Gln and subsequently using these values in the calculation of NPCF is not advisable as it may incorrectly estimate the amounts of Asn and Gln amino acids and their nitrogen content, resulting in an unreliable NPCF. The use of the universal NPCF of 6.25 is not reliable either as it overestimates the true protein content in cereal grains.

Acknowledgment: This work was supported by the 1890 Capacity Building Grants [grant no. 2015-38821-24363/project accession no. 1007423] from the USDA National Institute of Food and Agriculture.

\section{REFERENCES}

Association of Official Analytical Chemists (AOAC). (2006).Official Methods of analysis of AOAC International.In: Latimer, G. W., Horwitz W(eds), 18th Edition. AOAC, Washington, D.C.ISBN 093558477. https://doi.org/10.1016/s0003-2670(00)86185-1

Boisen, S., Hvelplund, T., \& Weisbjerg, M. R. (2000). Ideal amino acid profiles as a basis for feed protein evaluation. Livestock Production Science, 64(2-3), 239-251. https://doi.org/10.1016/S0301-6226(99)00146-3

Chan, D. S., Lau, R., Aune, D., Vieira, R., Greenwood, D. C., Kampman, E., \& Norat, T. (2011). Red and processed meat and colorectal cancer incidence: metaanalysis of prospective studies. Public Library of Science One, 6(6), e20456. https://doi.org/10.1371/journal.pone.0020456

Dvoracek, V., Curn, V., \& Moudry, J. (2002). Evaluation of Amino Acid Content and Composition in Spelt Wheat Varieties. Cereal Research Communications, 30(2002), 187-193.

Food and Agriculture Organization (FAO) of the United Nations. (1981). Amino Acid Scoring Patterns. Joint FAO/WHO/UNU Expert consultation on energy and protein requirements, Provisional Agenda Item 3.2.3. Food and Agriculture Organization/World Health Organization /United Nations University ESN FAO/WHO/UNU EPR/81/31. http://www.who.int/iris/handle/10665/39527 Food and Nutrition Board (FNB). (1989). Recommended Dietary Allowances, $10^{\text {th }}$ Edition. National Academy of Science, USA. https://doi.org/10.17226/1349 
Friedman, M. (1996). Nutritional value of proteins from different food sources. A review. Journal of Agricultural and Food Chemistry, 44(1), 6-29. https://doi.org/10.1021/jf9400167

Fujihara, S., Sasaki, H., Aoyagi, Y., \& Sugahara, T. (2008). Nitrogen-to-protein conversion factors for some cereal products in Japan. Journal of Food Science, 73(3), 204 -209. https://doi.org/10.1111/j.1750-3841.2008.00665.x

Ibegbulem, C. O., Igwe, C. U., Okwu, G. N., Ujowundu, C. O., Onyeike, E. N., \& Ayalogu, E. O. (2013). Total amino acid profiles of heat-processed fresh Elaeis guineensis and Raphia hookeri wines. Food Chemistry, 138(2-3), 16161620. https://doi.org/10.1016/i.foodchem.2012.11.110

Izhaki, I. (1993). Influence of nonprotein nitrogen on estimation of protein from total nitrogen in fleshy fruits. Journal of Chemical Ecology, 19(11), 2605-2615. https://doi.org/10.1007/BF0098069

Janssen, R. H., Lambertus, J. V., Van Den Broek, A. M. Fogliano, V., \& Lakemond, M. M. C. (2017). Nitrogen-to-Protein Conversion Factors for Three Edible Insects: Tenebrio molitor, Alphitobius diaperinus, and Hermetia illucens. Journal of Agricultural and Food Chemistry, 65(11), 2275-2278. https://doi.org/10.1021/acs.jafc.7b00471

Jones, D. B. (1931). Factors for converting percentages of nitrogen in foods and feeds into percentages of protein. United States Department of Agriculture Circular 1931, No.183 reference 105, 1-21.

Levey, D. J., Bissell, H. A., \& O'keefe, S. F. (2000). Conversion of nitrogen to protein and amino acids. Journal of Chemical Ecology, 26(7), 1749-63. https://doi.org/10.1023/A:1005503316406

Lourenco, S. O., Barbarino, E., Lanfer Marquez, U. M., \& Aidar, E. (1998). Distribution of intracellular nitrogen in marine microalgae: Basis for the calculation of specific nitrogen-to-protein conversion factors. Journal of Phycology, 39 (1), 798-811. https://doi.org/10.1080/0967026032000157156

Magomya, A. M., Kubmarawa, D., Ndahi, J. A., \& Yebpella, G. G. (2014) Determination of plant proteins via the Kjeldahl method and amino acid analysis: a comparative study. International Journal of Scientific and Technology Research, 3(4), 68-72.

Milton, K., \& Dintzis, F. R. (1981). Nitrogen-to-protein conversion factors for tropical plant samples. Biotropica, 13(3), 177-181. https://doi.org/10.2307/2388122

Misra, J. B. (2001). Variation in nitrogen-to-protein conversion factor for peanut. Peanut Science, 28(2), 48-51. https://doi.org/10.3146/i0095-3679-28-2-2

Mosse, J. (1990). Nitrogen-to-protein conversion factor for ten cereals and six legumes or oilseeds. A reappraisal of its definition and determination. Variation according to species and to seed protein content. Journal of Agricultural and Food Chemistry, 38(1), 18-24. https://doi.org/10.1021/jf00091a004

Multari, S., Neacsu, M., Scobbie, L., Cantlay, L., Duncan, G., Vaughan, N. Stewart, D., \& Russell, W. R. (2016). Nutritional and phytochemical content of high-protein crops. Journal of Agriculture and Food Chemistry, 64(41), 78007811. https://doi.org/10.1021/acs.jafc.6b00926

Nelson, D. L., \& Cox, M. M. (2008). Lehninger principles of biochemistry, Fifth Edition. ISBN 13:9780716771081. W.H. Freeman and Company. New York.

Nitrayova, S., Brestenský, M., Heger, J., Patras, P., Rafay, J., \& Sirotkin, A. (2014). Amino acids and fatty acids profile of chia (Salvia hispanica L.) and flax (Linum usitatissimum L.) $\quad$ seed. Potravinarstvo, 8(1), $72-76$. https://doi.org/10.5219/332

Pedersen, A. N., Kondrup. J., \& Børsheim, E. (2013). Health effects of protein intake in healthy adults: a systematic literature review. Food and Nutrition Research, 57(1), 21245. https://doi.org/10.3402/fnr.v57i0.21245

Pihlanto, A., Mattila, P. H., Mäkinen, S., \& Pajari, A. M. (2017). Bioactivities in alternative protein sources and their potential health benefits. Food and Function, 8(10), 3443-3458. https://doi.org/10.1039/c7fo00302a

Hackler L.R. (1985). Cereal Proteins in Human Nutrition. In: Lásztity R., Hidvégi M. (eds) Amino Acid Composition and Biological Value of Cereal Proteins. Springer, Dordrecht. https://doi.org/10.1007/978-94-009-5307-9 6

Russo, R., \& Reggiani, R. (2015). Evaluation of Protein Concentration, Amino Acid Profile and Antinutritional Compounds in Hempseed Meal from Dioecious and Monoecious Varieties. American Journal of Plant Sciences, 6(6),14-22. https://doi.org/10.4236/ajps.2015.61003

Salo-Vaananen, P. P., \& Koivistoinen, P. E. (1996). Determination of protein in foods: comparison of net protein and crude protein (N X 6.25) values. Food Chemistry, 57(1), 27-31. https://doi.org/10.1016/0308-8146(96)00157-4

Sedinger, J. S. (1984). Protein and amino acid composition of tundra vegetation in relation to nutritional requirements of geese. Journal of Wildlife Management, 48(4), 1128-1138. https://doi.org/10.2307/3801773

Shen, Y., Zheng, L., Jin, J., Li, X., Fu, J., Wang, M., Guan, Y., \& Song, X (2018). Phytochemical and Biological Characteristics of Mexican Chia Seed Oil. Molecules, 23(12), 3219. https://doi.org/10.3390/molecules23123219

Singh, K. K., Mridula, D., Rehal, J., \& Barnwal, P. (2011). Flaxseed: A potential source of food, feed and fiber. Critical Reviews in Food Science and Nutrition, 51(3), 210-222. https://doi.org/10.1080/10408390903537241

Tkachuk, R. (1969). Nitrogen-to-protein conversion factors for cereals and oilseed meals. Cereal Chemistry 46, 419-423. 